\title{
PROPORTION OF ANTICANCER ACTIVITY OF PROTEIN AND PROTEIN HYDROLYSATE FROM EPIPHYTIC BACTERIA
}

\author{
N. Asmi ${ }^{1}$, A. Ahmad ${ }^{1, *}$, H. Natsir ${ }^{1}$, M.N. Massi ${ }^{2}$, H. Karim ${ }^{3}$, H. Madhyastha ${ }^{4}$, \\ R. Madhyastha ${ }^{4}$, Y. Nakajima ${ }^{4}$ and M. Maruyama ${ }^{4}$ \\ ${ }^{1}$ Department of Chemistry, Faculty of Mathematics and Natural Science, Hasanuddin University, \\ Makassar 90245, Indonesia \\ ${ }^{2}$ Department of Microbiology, Faculty of Medicine, Hasanuddin University, Makassar 90245, \\ Indonesia \\ ${ }^{3}$ Department of Pharmacy, YAMASI, J1. Mapala 2 Blok D5 No.10 Makassar Indonesia \\ ${ }^{4}$ Department of Applied Physiology, Faculty of Medicine, University of Miyazaki, Miyazaki \\ 889-1692, Japan \\ *E-mail: ahyarahmad@gmail.com
}

\begin{abstract}
This research aimed to explore the anticancer potential in the protein and hydrolysate protein produced by epiphytic bacteria associated with marine algae on the in vitro model of lung cancer LK-2. Protein was isolated from the bacterium Enterobacter unhas strain SG-A1 in which has an association with brown algae, Sargassum sp. A fractionation method has used in separating the protein. It was used as a dialysis process added by Tris $\mathrm{HCl}$ to conduct pre-purified of the fractions, and the pepsin enzyme was used in producing protein hydrolysate $\left(\mathrm{pH} 2.0,37^{\circ} \mathrm{C}\right)$ at $3: 100$ ratio of enzyme-substrate. Pre-screening of toxicity can be conducted using BSLT or Brine Shrimp Lethality Test. The cytotoxic effects of protein and protein hydrolysate on LK-2 cell lines during $16 \mathrm{~h}$ were determined by the yellow tetrazolium salt 3-(4, 5- dimethylthiazol-2-yl)-2, 5-diphenyltetrazolium bromide (MTT) assay. The BSLT test revealed that the hydrolysate fractions were very toxic. It showed a higher magnitude of decreasing (significance $p<0.05)$ in cell viability in LK-2 cells. These findings suggested that the hydrolysate of protein produced by epiphytic bacteria brown algae associated, Sargassum sp. has a high probability of being used as cancer therapy agents.
\end{abstract}

Keywords: Anticancer, Epiphytic Bacteria, Lung Cancer, Sargassum sp, Protein Hydrolysate.

RASĀYAN J. Chem., Vol. 14, No.3, 2021

\section{INTRODUCTION}

It is known that human death in 2018 is mainly caused by cancer. Cancer has been responsible for 9.6 million cases of death, ${ }^{1}$ especially lung cancer. ${ }^{2}$ Various medicinal compounds are developed, with specific targets with no or fewer side effects, such as synthetic chemical compounds continually being developed. ${ }^{3}$ The global biodiversity of the marine environment represents half of the wealth of structural diversity and bioactive metabolites. The organisms living in the ocean and algae can be producers of bioactive compounds that can be developed as a therapeutic agent. The marine algae can be utilized as a source of bioactive materials, encouraging researchers to explore marine algae further. ${ }^{4}$ Each marine algae contains diverse proteins, one to others. It is about $5-15 \%$ of the protein content in marine algae, while red and green algae contain 10 to $47 \%$ of dry weight protein. Several types of algae have been reported to contain anticancer compounds. ${ }^{4}$ Algae are classified into marine eukaryotes that contain symbiotic bacteria. ${ }^{5}$ Symbiotic bacteria contain abundant potential chemical compounds as drugs diversely with unique physiological and natural functions. ${ }^{6,7}$

Nowadays, study protein and hydrolysate protein have been popular research that contributes to applying nutraceuticals and functional food ingredients. Enzymatic hydrolysis is preferred because it can produce specific or various hydrolysates according to the protease enzyme used. This study was completed in isolating anticancer protein and hydrolysate protein from Sargassum sp (brown algae). The proteins were obtained by the fractionation and dialysis process. After that, enzymatic hydrolysis is done by using pepsin enzymes at optimum conditions. Previous studies carried out using the trypsin enzyme but have not given 
maximum results at the pre-screening stage. So, in this study, enzymatic hydrolysis was carried out using a different protease enzyme. ${ }^{8}$ The pre-screening of anticancer agents was conducted using a method of BSLT. The anticancer's specific examination was performed in the present study using an MTT assay on lung cancer LK-2 cells. Lung cancer LK-2 is the pulmonary squamous cell carcinoma (SQ) cell lines. That is one example of NSCLC (non-small cell lung cancer), the leading cause of death. ${ }^{9}$ In this study, these cancer cells were used to screen protein and hydrolysate as candidates for bioactive compounds. The study reported that protein hydrolysate could be a new anticancer agent in cancer treatment, especially lung cancer LK-2.

\section{Isolation of Protein}

\section{EXPERIMENTAL}

The injection $(10 \%)$ of the isolated epiphytic bacteria from brown algae Sargassum sp mix into a fermentation medium with a similar composition inoculum medium. After that, rock bacteria at $180 \mathrm{rpm}$, $37{ }^{\circ} \mathrm{C}$ in a day, then homogenize the mixture of the bacteria by sonication with $100 \mathrm{ml}$ buffer A solution with the cell lysis. The crude extract was done during centrifugation at $5000 \mathrm{rpm}$ in 30 minutes at $4^{\circ} \mathrm{C}$ and 2-3 times for the Freeze-thaw process. ${ }^{10}$ Fractioning the protein at different saturation levels using the ammonium sulphate and the dialysis of protein fractions using a cellophane bag (Sigma).

\section{Hydrolysis of Protein}

Hydrolysis using the enzymatic method with modification is to obtain the protein of epiphytic bacteria from brown algae Sargassum sp. ${ }^{11}$ Evaluation of the extent of protein hydrolysis may be preserved by measuring hydrolysis degree (DH). The details of this assay have been described previously. ${ }^{8,12}$ The protein was diluted to $3 \%$ then hydrolyzed with the pepsin enzyme. The pepsin enzyme was added to a protein by comparing enzymes-substrates $1: 3$ at $37^{\circ} \mathrm{C}, \mathrm{pH} 2$ at the optimal condition. Deactivation of the enzyme can be done after hydrolysis. It was done by placing the sample in boiling water for 10 minutes. The hydrolysate collected must be centrifuged at $10.000 \mathrm{rpm}$, at $4^{\circ} \mathrm{C}$ for 20 minutes; ${ }^{13}$ the hydrolysate obtained can be stored at $-80^{\circ} \mathrm{C}$ for further study.

\section{Protein Concentration Determination}

Determination of protein level carried out using Pierce ${ }^{\mathrm{TM}}$ BCA Protein Assay Kit. The standard of the 10 $\mu 1$ in each standard replicate was added into a microplate well $(20 \mu \mathrm{g} / \mathrm{ml})$. Then, there is the addition of 80 $\mu 1$ to each well, and there is a mixture of plate shakers for 30 seconds, continue by the incubation ( $30 \mathrm{~min}$, $37^{\circ} \mathrm{C}$ ). The measurement of the $570 \mathrm{~nm}$ sample was done on the plate reader.

\section{Anticancer Activity \\ Toxicity test using the method of the Brine Shrimp Lethality Test (BSLT)}

The activity of the preliminary anticancer test was done using a BSLT method that utilizes Artemia Salina Leach. Shrimp eggs were hatched about 48 hours and after that the larvae are separated from their eggs by pipette into a test tube containing sterile seawater. ${ }^{14}$ The samples with a 100,10 , and 1 ppm concentration with $1 \mathrm{ml}$ volume were added into test tubes containing $4 \mathrm{ml}$ of sterile seawater and ten tail shrimp larvae. It needs 24 hours of exposure to counting the dead shrimp larvae. Test for each concentration was carried out three times and compared with controls. The toxicity data were obtained from the analysis of $\mathrm{LC}_{50}$ values, which was performed by probit test analysis. ${ }^{8,15}$

\section{MTT Assay}

Lung cancer LK-2 cell line was incubated in DMEM supplemented with heat-inactivated $100 \mathrm{ml} / 1$ fetal bovine serum, $100 \mathrm{U} / \mathrm{ml}$ penicillin, $100 \mathrm{mg} / \mathrm{ml}$ streptomycin. Culturalization of the cells was conducted in a humidified atmosphere of $5 \% \mathrm{CO}_{2}$ at $37^{\circ} \mathrm{C}$. There was a change of the medium every day.

MTT assay is used to examine the influence of protein and hydrolysates on cell growth and survival. There were about $1 \times 10^{4}$ distributed to the 96 well plates. The cells were incubated for 24 hours, and then the cells were handled with fractions with several doses and incubated for $16 \mathrm{~h}$. Each well was added $50 \mathrm{ml}$ of MTT in PBS $(0.5 \mathrm{mg} / \mathrm{ml})$, and the cells were incubated for 4 hours. The addition of $100 \mathrm{ml}$ of DMSO can solubilize the MTT formazan crystals to each well. A microplate reader was used to measuring the 
RASĀYAN J. Chem.

Vol. 14 | No. 3 |1594-1599| July - September | 2021

absorbance at $570 \mathrm{~nm}$ using ELISA reader. The absorbance was taken in 100\% viability of the control cells. The results can be described as the percentage of viable cells versus the respective controls. ${ }^{16,17}$

\section{Isolation of Protein from Epiphytic Bacteria}

\section{RESULTS AND DISCUSSION}

Multilevel dilution methods for brown algae were used to grow the bacterial isolates. The estimated microbes suspended in the liquid become the consideration in the dilution process. The pure isolate was chosen. The identification of isolate was carried out by molecular identification by sequencing $16 \mathrm{~S}$ rRNA, and it is identified as Enterobacter unhas SG-A1. ${ }^{11}$

The fractionation of crude extract is conducted at different saturation levels of ammonium sulphate. The process of fractionation is a purification method based on protein solubility. Protein deposits obtained from the fractionation process using sulfuric acid containing high salinity. The remaining salts in the deposition process are separated by dialysis using a cellophane membrane in the buffer $\mathrm{C}$ solution. Dialysis is a further refining process. The dialysis process ends when the buffer $\mathrm{C}$ solution used during dialysis does not turn cloudy when added with the $\mathrm{BaCl}_{2}$ solution. This method is usually used to dissolve liquids used in the membrane systems. Small molecules will escape from the membrane pores, and the larger molecules do not get away from the membrane.

Measurement of obtained dialysate by protein content and toxicity test in each fraction was conducted after the dialysis process. Table-1 shows that protein levels in each protein fraction are not similar due to different protein solubility in the water; hence the protein that settles shows differences. The comparison was made between the lack of solubility protein to the higher solubility in the water. The F1 (0-20\%) fraction shown the highest level. From these data, it can be assumed that protein fractions have a sufficiently high solubility in water.

Table-1: The Protein Concentration from Epiphytic Bacteria Enterobacter unhas SG-A1

\begin{tabular}{c|c|c|c|c}
\hline No. & Fraction & Volume (ml) & Protein Level $(\mathrm{mg} / \mathrm{ml})$ & Total Protein $(\mathrm{mg})$ \\
\hline 1 & Crude Extract (F0) & 7.20 & 12.50 & 90.00 \\
\hline 2 & $0-20 \%(\mathrm{~F} 1)$ & 5.10 & 10.85 & 55.35 \\
\hline 3 & $20-40 \%(\mathrm{~F} 2)$ & 2.70 & 10.66 & 28.78 \\
\hline 4 & $40-60 \%(\mathrm{~F} 3)$ & 4.30 & 11.76 & 50.57 \\
\hline 5 & $60-80 \%(\mathrm{~F} 4)$ & 2.80 & 10.66 & 29.85 \\
\hline
\end{tabular}

\section{Hydrolysis of Protein}

The protein hydrolysis process was conducted by the method of utilizing enzymes. Evaluation of the extent of protein hydrolysis can be tested by measuring the degree of hydrolysis (DH). The DH yields obtained by the TCA methods followed the previous research. ${ }^{8}$ The DH of protein is presented in Fig.- 1 . The soluble protein content in TCA gave the optimum result at 90 minutes in producing the hydrolysates.

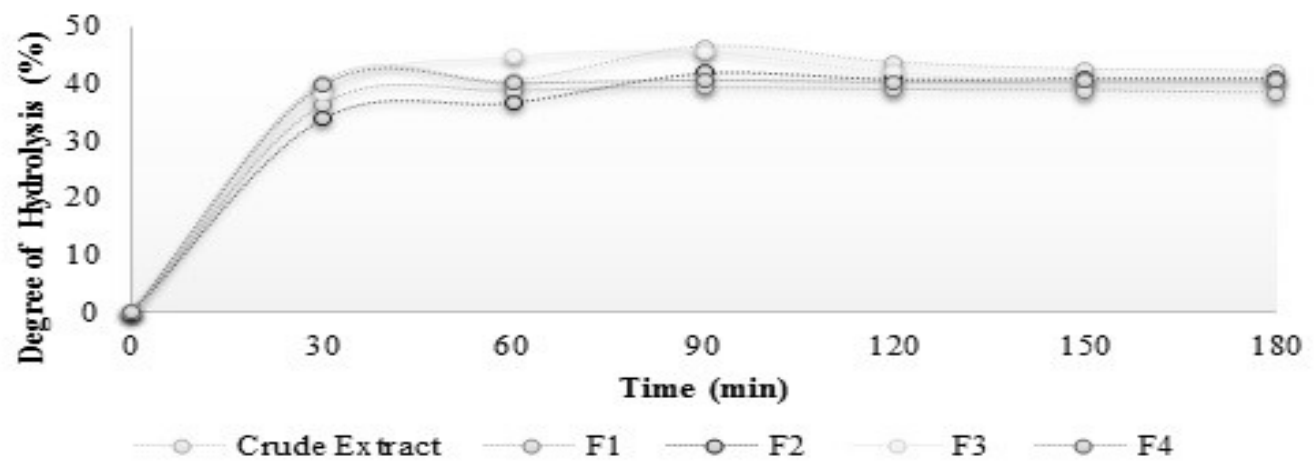

Fig.-1: The Percentage of DH of Protein Hydrolysate from Epiphytic Bacteria associate with Sargassum sp Anticancer Activity

Toxicity by BSLT Methods

The toxicity effect was performed by $\mathrm{LC}_{50}$ confirmation. The BSLT method is the proper method for filtering compounds that potentially contain anticancer bioactivity. It is affordable to conduct, needs a 
RASĀYAN J. Chem.

Vol. 14 | No. 3 |1594-1599| July - September | 2021

shorter time, more comfortable to be evolved, and no ethical instruction in test material use. The probit-log concentration graph can be used to identify the $\mathrm{LC}_{50}$ values. The death of Artemia salina L. being a parameter to indicate the presence of any active toxic substance. If the $\mathrm{LC}_{50}<1000 \mu \mathrm{g} / \mathrm{ml}$ value is toxic, conversely, the $\mathrm{LC}_{50}>1000 \mu \mathrm{g} / \mathrm{ml}$ value is said to be non-toxic for crude extract, and $<30 \mu \mathrm{g} / \mathrm{ml}$ for a pure compound is said to be toxic. ${ }^{14}$ The more minor the $\mathrm{LC}_{50}$ value, the more toxic the test compound is. The calculation results of the $\mathrm{LC}_{50}$ value of protein fractions are shown in Fig.-2. The $\mathrm{LC}_{50}$ values obtained show that protein fractions from epiphyte bacteria are very toxic and increase after hydrolysis. The fraction of protein and hydrolysate at $60-80 \%$ (F4) saturation gave the highest toxicity response to Artemia salina L. shrimp with an $\mathrm{LC}_{50}$ value of $0.34 \mu \mathrm{g} / \mathrm{ml}$ and $0.17 \mu \mathrm{g} / \mathrm{ml}$, respectively. Fraction F4 was chosen to be used at the next stage. This study provides higher activity than hydrolysates produced using the trypsin enzyme. ${ }^{8}$

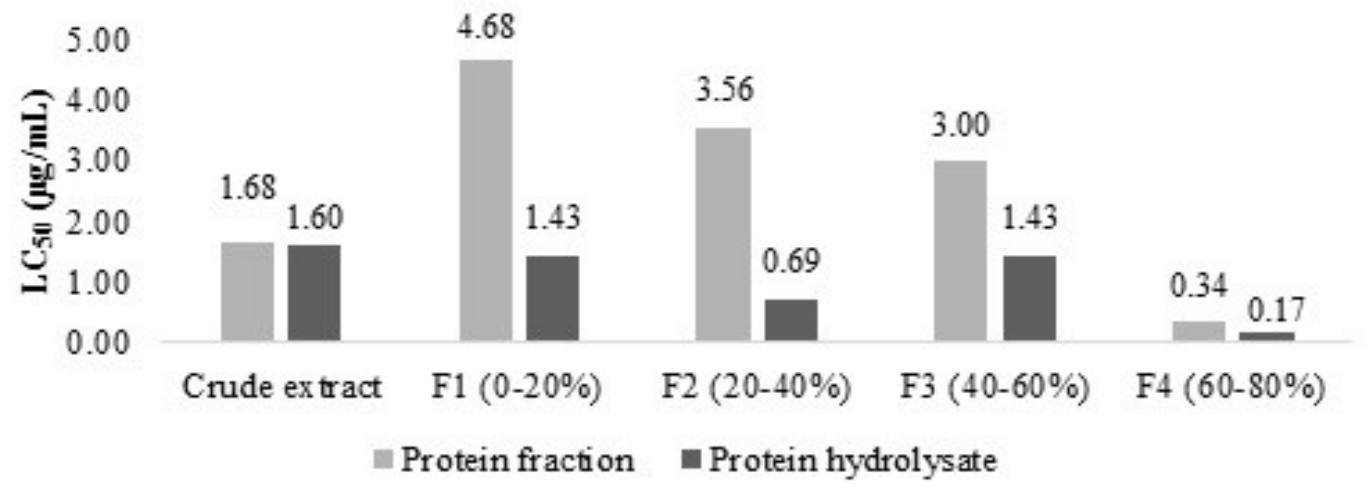

Fig.-2: Value of $\mathrm{LC}_{50}$ Calculation Results from Protein Fraction and Protein Hydrolysates

\section{Cytotoxicity by MTT Assay}

The anticancer activity of the crude extract, $\mathrm{F} 4 \mathrm{p}$ protein fraction, and $\mathrm{F} 4 \mathrm{~h}$ protein hydrolyzate was evaluated based on cell viability and cell proliferation. Cell viability is the ability of cells to survive after exposure to a substance, while cell proliferation is the ability of cells to reproduce themselves. In theory, the greater the concentration of the extract given, the smaller the percentage of cancer cell viability, as well as the longer the exposure of a substance to cancer cells at a certain concentration, the stronger the cell proliferation ability. The assay of MTT was conducted in determining the effect of cytotoxic protein fractions and protein hydrolysate on the LK-2 cell lines. Treatment with protein and protein hydrolysate decreased cell proliferation rate at $16 \mathrm{~h}$ in the LK-2 cells; F4 h decreased significantly (Fig.-3).

The fractions were applied to cells at various concentrations. There was a calculation of the percentage of cell viability values. It can be seen in Fig.-4. The rate of cell death of LK-2 in crude extracts of protein obtained from epiphytic bacteria associated with brown algae did not increase significantly. Protein fraction (F4p) and protein hydrolysate (F4h) provide almost the same inhibition. F4p shows the maximum concentration to inhibit the cell is $40 \mu \mathrm{g} / \mathrm{ml}$. The activity of F4h shows that increasing the protein concentration increases inhibitory activity. In this case, the protein hydrolysate is highly being considered as a candidate for cancer therapy. Protein hydrolysate has high activity caused by the protein hydrolysate and has broken down into smaller peptide fragments, so penetration into cancer cells is easier. The previous research showed the potency of protein from exophytic bacteria from Sargassum sp as an anticancer agent after hydrolyzed by the pepsin enzyme. ${ }^{18}$

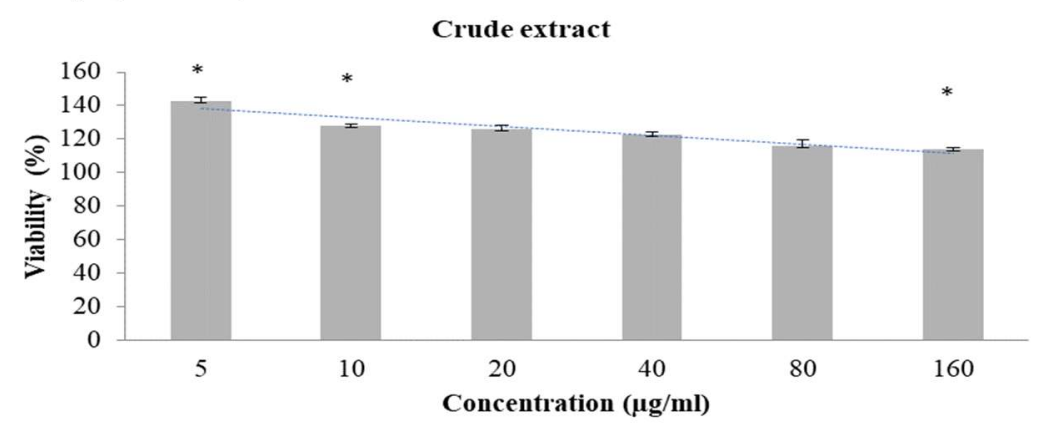


RASĀYAN J. Chem.

Vol. 14 | No. 3 |1594-1599| July - September | 2021

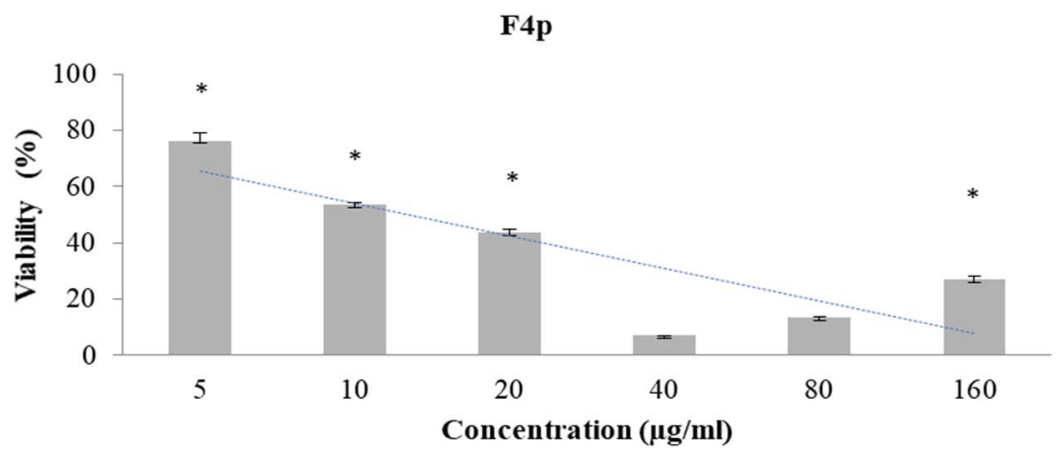

F4h

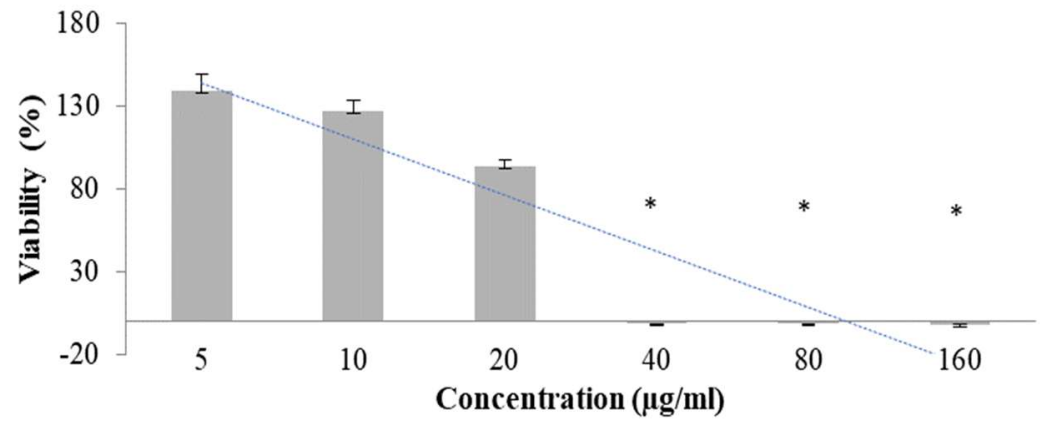

Fig.-3: Cytotoxicity Test based on MTT Assay. Representative Cell Viability Bar Graphs of LK-2 Cells line were treated with Different Crude Extract Concentrations, Protein Fraction (F4p), and Protein Hydrolysate (F4h) for 16 hours. Each Value is the mean $\pm \mathrm{SD}$ of three independent experiments. ${ }^{*} P<0.05$ compared with control

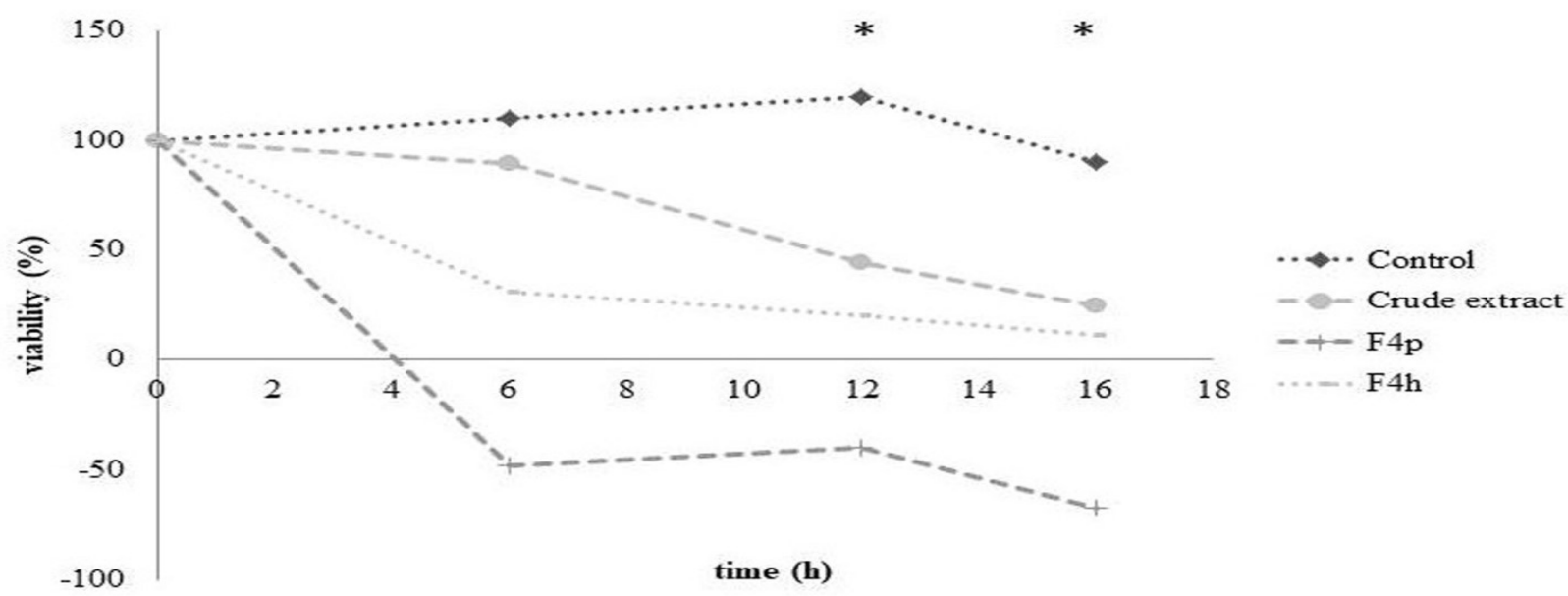

Fig.-4: Cell Proliferation Assay. The Effect of Cell Viability on LK-2 Cells after the treatment with Different Crude Extract concentrations, Protein Fraction (F4p), and Protein Hydrolysate (F4h) after 0, 6, 12, and $16 \mathrm{~h}$ of incubation were counted through MTT assay. Each value is the mean \pm SD of three independent experiments. ${ }^{*} P<0.05$ compared with control

\section{CONCLUSION}

Bioactive protein was isolated from the association between bacteria and brown algae Sargassum sp, and it can be hydrolyzed by the pepsin enzyme. These protein hydrolysates display anticancer activity against lung cancer LK-2 cell line at $16 \mathrm{~h}$. The results reported in this study indicate a potential protein hydrolysate to be a new invention of anticancer agents in treating cancer, especially lung cancer. 
RASĀYAN J. Chem.

Vol. 14 | No. 3 |1594-1599| July - September | 2021

\section{ACKNOWLEDGMENT}

Thank you to the PMDSU Scholarship scheme from the Indonesian Ministry of Education and Culture (KEMDIKBUD). This study is also supported by Sabbatical Leave and the Sandwich-like Program by KEMDIKBUD.

\section{REFERENCES}

1. X. Wang and X. Zhang, Biotechnology Progress, 29(3), 681(2013), https://doi.org/10.1002/btpr.1725

2. T. E-karbon, P. Thongararm, S. Roytrakul, L. Meesuk, P. Chumnanpuen, Computational and Structural Biotechnology Journal, 14, 49(2016), https://doi.org/10.1016/j.csbj.2015.11.005

3. P. Habbu, V. Warad, R. Shastri, S. Madagundi and V.H. Kulkarni, Chinese Journal of Natural Medicines, 14(2), 101(2016), https://doi.org/10.1016/S1875-5364(16)60003-1

4. X. Fan, L.Bai, L. Zhu, L. Yang and X. Zhang, Journal of Agricultural and Food Chemistry, 62, 92119222 (2014), https://doi.org/10.1021/jf502420h

5. K. Chakraborty, B. Thilakan, V.K. Raola and M. Joy, Food Chemistry, 218, 427(2 017), https://doi.org/10.1016/j.foodchem.2016.09.066

6. P.A. Harnedy and R.J. FitzGerald, Journal of Phycology, 47(2), 218(2011), https://doi.org/10.1111/j.1529-8817.2011.00969.x

7. A. Trevilov, M. Imendoerffer, G. Sekot, F. Strob, A. Jungbauer and R. Hahn, Journal of Biotechnology, 207, 21-29 (2015), https://doi.org/10.1016/j.jbiotec.2015.04.023

8. N. Asmi, A. Ahmad, M.N. Massi and H. Natsir, Journal of Physics: Conference Series, 1341(2019), 1(2019), https://doi.org/10.1088/1742-6596/1341/3/032013

9. T. Watanabe, T. Miura, Y. Degawa, Y. Fujita, M. Inoue and M. Kawaguchi, Cancer Cell International, 10, 1(2010), https://doi.org/10.1186/1475-2867-10-2

10. D. Liu, X. Zeng, D. Sun and Z. Han, Innovative Food Science, and Emerging Technologies, 18, 132(2013), https://doi.org/10.1016/j.ifset.2013.02.006

11. N. Asmi, A. Ahmad, M.N. Massi and H. Natsir, International Research Journal of Pharmacy, 10(6), 10(2019), https://doi.org/10.7897/2230-8407.1006195

12. N. Asmi, A. Ahmad, M.N. Massi, H. Natsir, A. Karim, P. Taba, Z. Dwyana and M. Ibrahim M, Rasayan Journal of Chemistry 13(3), 1606(2020), https://doi.org/10.31788/RJC.2020.1335696

13. H. Natsir, S. Dali, Sartika, Leliani and A.R. Arif, Rasayan Journal of Chemistry, 14(1), 594(2021), https://doi.org/10.31788/RJC.2021.1415914

14. Supomo, E.S. Syamsul, A. Apriliana, C. Saleh, Erwin and D. Lestari, Rasayan Journal of Chemistry, 12(3), 1340(2019), https://doi.org/10.31788/RJC.2019.1235264

15. A. Ahmad, H. Usman, H. Natsir and A. Karim, American Journal of Biomedical and Life Sciences, 2(5), 134(2014), https://doi.org/10.11648/j.ajbls.20140205.15

16. H. Madhyastha, M. Yamaguchi, H. Sameshima, T. Ikenoue and M. Maruyama. Biomed Research Internasional, 2013, 1(2013), https://doi.org/10.1155/2013/963457

17. E.E. Aung, A. N. Kristanti, N.S. Aminah, Y. Takaya, R. Ramadhan and H.T. Aung, Rasayan Journal of Chemistry, 14(1), 312(2021), https://doi.org/10.31788/RJC.2021.1416106

18. A. Ahmad, N. Asmi, H. Karim, M.N. Massi, I. Wahid and A. Sugrani, Journal of Applied Pharmaceutical Science, 11(2), 39(2021), https://doi.org/10.7324/JAPS.2021.110205

[RJC-6313/2020] 